\title{
Toxin gene determination and evolution in scorpaenoid fish
}

\author{
Po-Shun Chuang, Jen-Chieh Shiao* \\ Institute of Oceanography, National Taiwan University, Taipei, Taiwan
}

\section{A R T I C L E I N F O}

\section{Article history:}

Received 20 April 2014

Received in revised form 11 June 2014

Accepted 12 June 2014

Available online 17 June 2014

\section{Keywords:}

Scorpaenoidei

Scorpionfish

Rockfish

Toxin gene

Evolution

\begin{abstract}
A B S T R A C T
In this study, we determine the toxin genes from both cDNA and genomic DNA of four scorpaenoid fish and reconstruct their evolutionary relationship. The deduced protein sequences of the two toxin subunits in Sebastapistes strongia, Scorpaenopsis oxycephala, and Sebastiscus marmoratus are about 700 amino acid, similar to the sizes of the stonefish (Synanceia horrida, and Synanceia verrucosa) and lionfish (Pterois antennata and Pterois volitans) toxins previously published. The intron positions are highly conserved among these species, which indicate the applicability of gene finding by using genomic DNA template. The phylogenetic analysis shows that the two toxin subunits were duplicated prior to the speciation of Scorpaenoidei. The precedence of the gene duplication over speciation indicates that the toxin genes may be common to the whole family of Scorpaeniform. Furthermore, one additional toxin gene has been determined in the genomic DNA of Dendrochirus zebra. The phylogenetic analysis suggests that an additional gene duplication occurred before the speciation of the lionfish (Pteroinae) and a pseudogene may be generally present in the lineage of lionfish.
\end{abstract}

(C) 2014 Elsevier Ltd. All rights reserved.

\section{Introduction}

Animal venoms have long been studied due to their potential applicability for pharmacological and physiological purposes and have provided a rich pharmacopoeia (Menez, 1998; Church and Hodgson, 2002; Tan et al., 2003; Baron et al., 2013). The development of antitoxins is another field that has been intensively studied (Theakston, 1983; Chippaux and Goyffon, 1998; Huston and George, 2001; Gazarian et al., 2005; Wesolowski et al., 2009). The large number of accidents caused by animal envenomation per year makes the development of effective antivenins essential and valuable. In addition to the pharmacological applications, the diversity of the targets and the specificity of animal toxins make them useful tools in investigating the physiological functions or cellular localization of

\footnotetext{
* Corresponding author.

E-mail address: jcshiao@ntu.edu.tw (J.-C. Shiao).
}

various ion channels and cellular receptors (Terlau and Olivera, 2004; Dutertre and Lewis, 2010; Baron et al., 2013). Although numerous toxins extracted from terrestrial creatures have been studied and many of them have been in various stages of drug development (Newman and Cragg, 2012), marine toxins are largely ignored due to the difficulty in accessing them (Church and Hodgson, 2002; Jha and Zi-Rong, 2004; Smith and Wheeler, 2006). The majority of marine toxin studied have been from mollusca such as marine snails (Terlau and Olivera, 2004; Lu et al., 2014), leaving fish as a potent pool for new toxin discoveries.

Among the acanthomorpha, more than 1200 species are believed to be venomous (Smith and Wheeler, 2006). The phylogenetic tree constructed by Smith and Wheeler (2006) suggests that a high density of venomous species are present in the Scorpaenoidei, the suborder containing the most notorious venomous fishes: stonefish (genus Synanceia), lionfish (genera Pterois, Parapterois and Dendrochirus), and scorpionfish (genus Scorpaena). However, studies on the venom's properties are frequently impeded 
by the labiality of these proteins. To date, only several toxins from stonefish (Kreger, 1991; Garnier et al., 1997b; Khoo, 2002; Ueda et al., 2006), lionfish (Kiriake and Shiomi, 2011), scorpionfish (Schaeffer et al., 1971; Hahn and O'connor, 2000, Carrijo et al., 2005; Nagasaka et al., 2009; Andrich et al., 2010), devil stinger and waspfish (Shiomi et al., 1989) have been characterized for their bioactivities. Although these toxins have not been compared systematically, they all show hemolytic activity against various animal erythrocytes (Church and Hodgson, 2002). Since no phospholipase $A_{2}$ activity was found in any of these fish toxins (Shiomi et al., 1989; Poh et al., 1991; Hahn and O'connor, 2000, Andrich et al., 2010, Gomes et al., 2013), the hemolysis is believed to be from a nonenzymatic mechanism, as seen in some reptilian and amphibian toxins (Kini and Evans, 1989a). Studies using chemical modification methods further demonstrated that free thiol groups, tryptophans, and positively charged amino acid residues (such as Lys and Arg) play significant roles in the cytolytic activity of SNTX, the toxin extracted from Synanceia horrida (Chen et al., 1997; Khoo et al., 1998; Yew and Khoo, 2000). However, being that no mutagenesis studies have been conducted on this protein, the precise positions of the functional amino acid residues responsible for the hemolytic activity remain unknown.

In addition to the similarity in bioactivities, the crossreactivity of the commercial stonefish antivenom (SFAV) against toxins from different scorpaenoid indicates the presence of structural similarity between these toxins (Shiomi et al., 1989; Andrich et al., 2010, Gomes et al., 2011). A thorough comparative study of the amino acid sequences might improve our understanding of the reacting sites and the operating mechanism of these molecules. Unfortunately, only four toxins from the stonefish (three from Synanceia and one from Inimicus japonicus), three from genus Pterois, and one from the waspfish (Hypodytes rubripinnis) have had their primary structures determined (Ghadessy et al., 1996; Garnier et al., 1997a; Ueda et al., 2006; Kiriake and Shiomi, 2011; Kiriake et al., 2013). The determined toxins belong to a novel protein family composed of two different subunits with no similar protein or peptide found in GenBank. Meanwhile, multiple alignments of these venom protein sequences show high similarities between (50\%-80\%) and within (>80\%) the two subunits (Ueda et al., 2006; Kiriake and Shiomi, 2011; Kiriake et al., 2013). It was therefore hypothesized that these toxins evolved from a common ancestor peptide (Ghadessy et al., 1996; Ueda et al., 2006; Kiriake and Shiomi, 2011). However, testing this hypothesis has not been possible due to the scarcity of the sequence data and the narrow distribution of these sequences to only four genera (Synanceia, Pterois, Inimicus and Hypodytes).

In this study we cloned the toxin genes of several scorpaenoid fish collected from northern to northeastern Taiwan. By determining the gene sequences, we aim to: 1) reconstruct the evolutionary history of the toxin genes in Scorpaenoidei and clarify their evolutionary origin, and 2) identify the conserved regions of the venom peptides and infer the probable roles of these amino acid sites.

\section{Materials and methods}

\subsection{Sample collection and species identification}

Three species of live scorpaenoid fish (the barchin scorpionfish Sebastapistes strongia, the tassled scorpionfish Scorpaenopsis oxycephala, and the false kelpfish Sebastiscus marmoratus) and one species of dead fish (the zebra lionfish Dendrochirus zebra) were purchased from Nanfang-ao and Keelung and transferred to the laboratory for further experiments. The pictures of the collected samples are shown in Fig. 1 and the detailed information is listed in Table 1.

\subsection{RNA and DNA extraction}

Total RNA of S. strongia, S. oxycephala, and S. marmoratus was extracted from the dorsal spines following the Trizol RNA isolation protocol. For all study species, DNA was also extracted from muscle tissue using the DNeasy Blood \& Tissue Kit (QIOGEN) following the manufacturer's instructions.

\subsection{Primer design}

Gene-specific primers for the four species were designed from the determined nucleotide sequences obtained from Section 2.4. For the two subunit genes of $S$. strongia, $S$. oxycephala, and $S$. marmoratus, two degenerate forward primers (Uni_A and Uni_B) were designed from the conserved regions to amplify the middle regions of each of the two subunits. Degenerate primers were also designed from the sequences around start and stop codon according to cDNA sequences obtained in this study and from GenBank. These primers were named by their annealing regions (beginning) and their target genes (ending) (Table 2): start for forward primers annealing to the start-codon regions, stop for the reverse primers annealing to the stop-codon regions; primer names ending with $A$ or $B$ correspond to the $\alpha$ and $\beta$ subunits of the toxin genes; primer names ending with syn or pter were designed from the toxin genes in genus Synanceia or Pterois; and those ending with mar were species-specific primers for S. marmoratus.

For D. zebra, three distinct sequences were obtained by PCR using primers DegF1 and DegR. Three gene-specific primers (zebA, zebB, and zebC) were thus designed to amplify each individual gene. The sequences determined were then used to design the gene-specific primers to amplify the upstream and downstream sequences of the toxin genes of $D$. zebra. All the primers designed and used in this study are shown in Table 2.

\section{4. $R T-P C R$}

The first-strand cDNA was directly synthesized from $5 \mu \mathrm{g}$ of total RNA using the 3' RACE System for Rapid Amplification of cDNA Ends (invitrogen). The three degenerate primers (DegF1, DegF2, and DegR) designed by Kiriake and Shiomi (2011) were used and the reaction of RT-PCR was conducted following the protocol described 

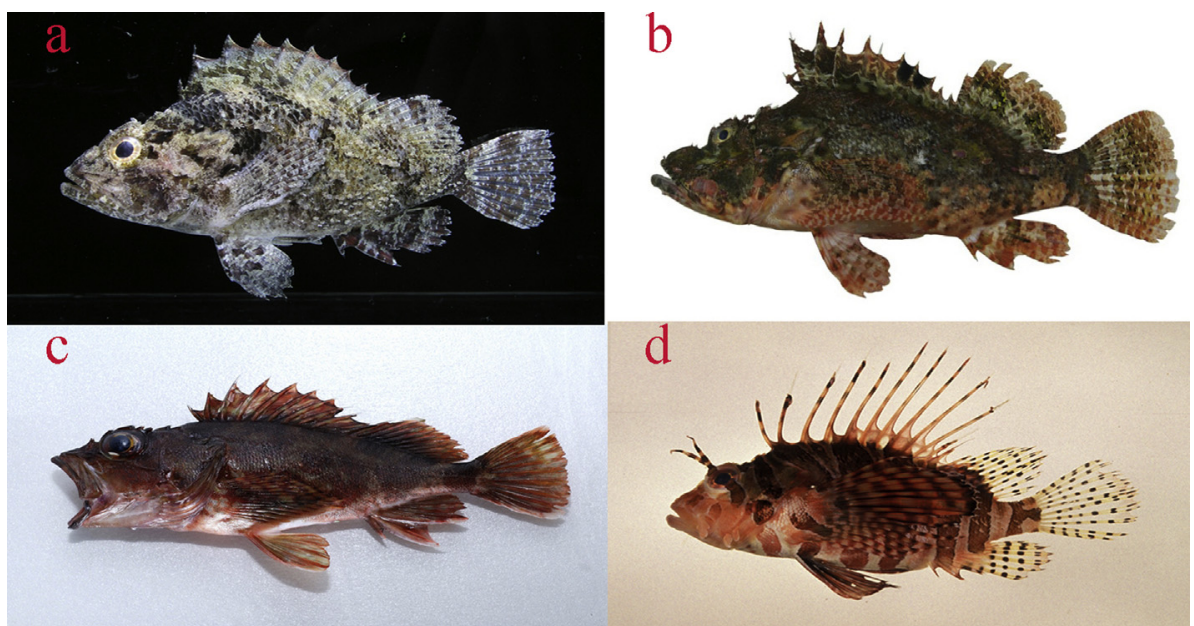

Fig. 1. Scorpaenoid fish of Sebastapistes strongia (a), Scorpaenopsis oxycephala (b), Sebastiscus marmoratus (c) and Dendrochirus zebra (d). Image source: the fish database of Taiwan, courtesy of Kwang-Tsao Shao, Wei-Chuan Chiang and Nian-Hong Jang-Liaw.

by Kiriake and Shiomi (2011), with a total volume of $25 \mu \mathrm{L}$ containing $0.2 \mu \mathrm{L}$ of TaKaRa Ex Taq ( $5 \mathrm{U} / \mu \mathrm{L}$, TaKaRa), $2.5 \mu \mathrm{L}$ of $2.5 \mathrm{mM}$ dNTP Mixture (TaKaRa), $2.5 \mu \mathrm{L} 10 \times$ Ex Taq Buffer (20 mM Tris- $\mathrm{HCl}, 100 \mathrm{mM} \mathrm{KCl,} 0.1 \mathrm{mM}$ EDTA, $1 \mathrm{mM}$ DTT, 0.5\% Tween 20, 0.5\% Nonidt P-40, 50\% Glycerol, $20 \mathrm{mM}$ $\mathrm{MgCl}_{2}, \mathrm{pH} 8.0$, TaKaRa), and $0.4 \mu \mathrm{M}$ of each primers. The PCR condition was set with an initiation step at $95^{\circ} \mathrm{C}$ for $3 \mathrm{~min}$, followed by 35 cycles of $95^{\circ} \mathrm{C}$ for $30 \mathrm{~s}, 55^{\circ} \mathrm{C}$ for $30 \mathrm{~s}$, $72{ }^{\circ} \mathrm{C}$ for $60 \mathrm{~s}$, and finished with a final extension step at $72{ }^{\circ} \mathrm{C}$ for $5 \mathrm{~min}$. The PCR products were subcloned into the pGEM-T Easy Vector (Promega) and sequenced by the Center for Biotechnology, National Taiwan University.

\subsection{RACE}

For 3' RACE, the cDNA synthesis procedure was the same as described in Section 2.4. Following cDNA synthesis, nested-PCR was carried out to amplify the $3^{\prime}$ UTR. The first reaction of nested-PCR was conducted with AUAP (5'GGCCACGCGTCGACTAGTAC- $3^{\prime}$ ) and the designed genespecific primer (str3A1/str3B1 for the two subunits of $S$. strongia, oxy3A1/oxy3B1 for $S$. oxycephala, mar3A1/mar3B1 for $S$. marmoratus) and run for 20 cycles. Following that, the PCR product was $50 \times$ diluted and served as template for the second PCR using primer AUAP and another genespecific primer (str3A2/str3B2 for $S$. strongia, oxy3A2/ oxy3B2 for $S$. oxycephala, mar3A2/mar3B2 for $S$. marmoratus) and run for 35 cycles.

For 5' RACE, the first-strand cDNA was synthesized from $5 \mu \mathrm{g}$ of total RNA using the $5^{\prime}$ RACE System for Rapid Amplification of cDNA Ends, Version 2.0 (invitrogen) with the gene-specific primer (str5_RACE for S. strongia, oxy5_RACE for S. oxycephala, and mar5_RACE_A/mar5_RACE_B for S. marmoratus). The first PCR was carried out using the gene-specific primer (str5A1/str5B1 for $S$. strongia, oxy5A1/oxy5B1 for S. oxycephala, mar5A1/mar5B1 for S. marmoratus) and AAP (5'-GGCCACGCGTCGACTAGTACGGGGGGGGGGGGGGGG-3' ${ }^{\prime}$ ) and was run for 20 cycles as in $3^{\prime}$ RACE. The PCR product was $50 \times$ diluted and the
nested-PCR was run with the gene-specific primers (str5A2/str5B2 for $S$. strongia, oxy5A2/oxy5B2 for $S$. oxycephala, mar5A2/mar5B2 for $S$. marmoratus) and primer AUAP (5'-GGCCACGCGTCGACTAGTAC-3') for 35 cycles. The PCR conditions for both $3^{\prime}$ and $5^{\prime}$ RACE were the same as described in Section 2.4 and the final PCR products were subjected to DNA sequence.

\subsection{PCR from genomic DNA}

For the genomic DNA of the three collected-live species (S. strongia, S. oxycephala, and S. marmoratus), Uni_A and Uni_B in combination with DegR were used to amplify each of the two subunits. The degenerate primers designed from start-codon and stop-codon sequences were used in combination with the corresponding gene-specific primers to obtain the whole toxin genes (StartA + str5A2/oxy5A2/ mar5A2, StartB + str5B2/oxy5B2/mar5B2, StopA + str3A2/ oxy3A2, StopB + str3B2/oxy3B2, StopA_mar + mar3A2, StopB_mar + mar3B2).

For D. zebra, PCR was conducted in the same manner as described above with the following primer pairs (Startsyn + zeb5A1, Startpter + zeb5B1/zeb5C1, StopA + zeb3A1, Stoppter + zeb3B1/zeb3C1).

\subsection{Sequence analysis}

The sequences obtained in this study and those downloaded from the NCBI database (AB262392, AB262393, AB623220-AB623223, AB775453-AB775458, U32516, U36237) were aligned and analyzed using Molecular Evolutionary Genetics Analysis (MEGA) 5.2.1 (Tamura et al., 2011). The nucleotide composition was estimated and the selection pressure was estimated by counting the $d_{\mathrm{N}} / d_{\mathrm{S}}$ value (Muse and Gaut, 1994). The similarity of the deduced amino acid sequences was analyzed by an online tool called SIAS (Sequences Indentifies and Similarities) with PAM250 as the matrix for global similarity test. 
Table 1

Biological information of the scorpaenoid fish used in this study.

\begin{tabular}{|c|c|c|c|c|}
\hline Species & $N$ & $\begin{array}{l}\text { Sampling } \\
\text { location }\end{array}$ & Length $(\mathrm{cm})$ & Weight (g) \\
\hline Sebastapistes strongia & 2 & Nanfang-ao & $9.9-10.6$ & $34-44$ \\
\hline $\begin{array}{r}\text { Scorpaenopsis } \\
\text { oxycephala }\end{array}$ & 3 & $\begin{array}{l}\text { Nanfang-ao } \\
\text { and Keelung }\end{array}$ & $13.2-22.4$ & $93-411$ \\
\hline $\begin{array}{l}\text { Sebastiscus } \\
\text { marmoratus }\end{array}$ & 4 & Keelung & $15.1-22.3$ & $57-330$ \\
\hline Dendrochirus zebra & 3 & Nanfang-ao & $13.3-15.6$ & $86-137$ \\
\hline
\end{tabular}

\subsection{Phylogenic analysis}

The outgroup sequence was searched from the whole genome data by a BLAST search of the $\alpha$ subunit of stonustoxin (U36237) in the Ensembl database. Two open reading frame (ORF) sequences were found in the genome of the three-spined stickleback Gasterosteus aculeatus(groupXXI: 7994877-7996973 and groupXXI: 7958278-7960098) and were used as the outgroup (no homology of the $\beta$ subunit of stonustoxin (U32516) could be found in G. aculeatus). Molecular models for the deduced amino acid sequences were tested by the model testing program in MEGA 5 and the JTT model combined with the Gamma distributed mutation rates was chosen to construct the phylogenic trees using the Maximum Likelihood and Maximum Parsimony methods.

\section{Results}

\subsection{Toxin genes determination by $R T-P C R$}

RT-PCR using the primer pair DegF1 + DegR amplified a 1500 bp product in S. strongia, S. oxycephala, and S. marmoratus. Subcloning of the PCR products showed that two different gene fragments exist (named $X x T x \_A$ and $X x T x \_B$, $\mathrm{Xx}$ represents the abbreviation of species names), as in the cases of the stonefish toxins stonustoxin (U32516 and U36237) and neoverrucotoxin (AB262392 and AB262393) and the lionfish toxins discovered by Kiriake and Shiomi (2011). For S. marmoratus, cloning of the 1500 bp product determined only one type of gene, which was similar (75-77\%) to the $\alpha$ subunits of the stonefish toxins (thus was named SmTx_A). To get the $\beta$ subunit gene of $S$. marmoratus, another primer pair DegF2 + DegR was used and a product about 1300 bp was amplified. Subcloning of the $1300 \mathrm{bp}$ product resulted in two distinct gene fragments as found in the other two species, S. strongia and S. oxycephala.

\subsection{Toxin genes determination by RACE}

5' RACE experiments succeeded in both toxin subunits in S. strongia, S. oxycephala, and S. marmoratus. The $5^{\prime}$ UTRs amplified by nested-PCR are about 95 bp (92-97 bp) for all the toxin genes. For 3' RACE experiments, nested-PCR successfully amplified the $3^{\prime}$ UTRs in $S$. oxycephala and $S$. marmoratus, but did not result in any product in $S$. strongia. To get the whole coding region (CDR) sequences of $S$. strongia, the degenerate primers designed from the stopcodon regions were used to replace the universal primer
AUAP. Using the same cDNA template as in the $3^{\prime}$ RACE, primer pairs str3A2 + StopA and str3B2 + StopB successfully amplified a single product in the two toxin subunit genes in S. strongia, respectively. The determined 3' UTRs in S. oxycephala and S. marmoratus varied from 207 bp to $321 \mathrm{bp}$, while for S. strongia, the 3' UTRs were undetermined. The whole lengths of determined cDNA sequences of the two subunits are 2209 and 2194 bp in S. strongia, 2410 and 2428 bp in S. oxycephala, and 2437 and 2519 bp in $S$. marmoratus. The deduced amino acid sequences are 703 a.a. for the $\alpha$ subunits of $S$. strongia (SsTx_A) and S. oxycephala (SoTx_A) and 702 a.a. for S. marmoratus (SmTx_A). The $\beta$ subunits are 698 a.a. for $S$. strongia $\left(S s T x \_B\right)$ and $S$. oxycephala (SoTx_B) and 700 a.a. for S. marmoratus (SmTx_B). Table 3 summarizes the accession numbers, the lengths of UTRs, and the lengths of CDR of all the cDNA sequences determined in this study.

\subsection{Toxin genes determination from genomic DNA templates}

Degenerate primers Uni_A and Uni_B amplified the corresponding subunit genes in S. strongia, S. oxycephala, and $S$. marmoratus when using genomic DNA as the template. The PCR products were about 2200 bp for the $\alpha$ subunit genes and 2500 bp for the $\beta$ subunits. The dissimilarity in the lengths of PCR products from cDNA and genomic DNA indicates the existence of introns in the toxin genes. The whole sequences of the toxin subunit genes in the genomic DNA of S. strongia, S. oxycephala, and S. marmoratus were determined using gene-specific primers and degenerate primers designed from start- and stop-codon sequences. The lengths (from start codon to stop codon) of these two toxin genes are 5011 bp (SsTx_A) and 3988 bp $\left(S s T x \_B\right)$ in S. strongia, 4838 bp (SoTx_A) and 3488 bp (SoTx_B) in S. oxycephala and 3158 bp (SmTx_A) and $3821 \mathrm{bp}$ $\left(S m T x \_B\right)$ in $S$. marmoratus.

Since D. zebra data was collected from dead individuals, genomic DNA was used to amplify the toxin genes. Primer set DegF1 + DegR was used and the result showed three bands on the agarose gel, which ranged from 1500 to 2200 bp. Subcloning of the PCR products showed that three different products exist (named as $D z T x \_A, D z T x \_B$, and $\left.D z T x \_C\right)$. GSPs were then designed for each of the three genes. Combined with DegR, the designed GSPs (zebA, zebB, zebC) successfully amplified a single product for each gene. A preliminary phylogenetic analysis using the neighbor-joining method demonstrated that DzTx_A is more similar to $\alpha$ subunit of stonustoxin (U36237), while $D z T x \_B$ and $D z T x \_C$ are grouped with the two toxin subunit genes in the genus Pterois (data not shown). The upstream sequence of $D z T x \_A$ was therefore amplified using a primer designed from the start-codon regions of the $\alpha$ subunits of stonustoxin and neoverrucotoxin (primer named Startsyn). For $D z T x_{-} B$ and $D z T x_{-} C$, an additional primer was designed specifically for the start-codon region of lionfish (named Startpter). In an attempt to get the whole toxin sequences of $D$. zebra, primer sets Startsyn + zeb5A1, Startpter + zeb5B1 and Startpter + zeb5C1 successfully amplified the upstream sequences of these three toxin genes, respectively. However, we were unable to determine the downstream 
Table 2

Primers used in this study.

\begin{tabular}{|c|c|c|c|c|}
\hline Primer & Sequence & Position & Reference sequence & Source \\
\hline \multicolumn{5}{|c|}{ Universal/degenerate primers for all species in this study } \\
\hline FishF2 & 5'-CGACTAATCATAAAGATATCGGCAC-3' & & & Ward et al. (2005) \\
\hline FishR2 & 5'-ACTTCAGGGTGACCGAAGAATCAGAA-3' & & & \\
\hline DegF1 & 5'-GATGGATATTGAAGCMTCTC-3' & $260-279$ & stonustoxin_ $\alpha(\mathrm{U} 36237)$ & Kiriake and Shiomi (2011) \\
\hline DegF2 & 5'-GGGGCMAATGCYTTCTTTGT-3' & $498-517$ & stonustoxin_ $\alpha$ (U36237) & \\
\hline DegR & 5'-CСАСТСYАМСТСССАGTAAT-3' & $1823-1804$ & stonustoxin_ $\alpha$ (U36237) & \\
\hline Uni_A & 5'-GATATTGAAGCTTCTCTGGG-3' & $305-324$ & cDNA of $S s T x \_A(\mathrm{KJ} 689803)$ & This study \\
\hline Uni_B & 5'-GAYATWGAAGCTTCTCTGAA-3' & $305-324$ & cDNA of SsTx_B (KJ689804) & \\
\hline StartA & 5'-ATGYCTTCAGAYATCWTGRTAA-3' & $98-119$ & cDNA of SsTx_A (KJ689803) & \\
\hline StartB & 5'-ATGYCTTCAGAHATCWTGGTKG-3' & $98-119$ & cDNA of SsTx_B (KJ689804) & \\
\hline Startsyn & 5'-ATGTCTTCAGATTTGGTAATGC-3' & $60-81$ & stonustoxin_ $\alpha$ (U36237) & Ghadessy et al. (1996) \\
\hline Startpter & 5'-ATGTCYTCASAAATCTTGRTRG-3' & $80-101$ & $P v T x-a(\mathrm{AB} 623222)$ & Kiriake and Shiomi (2011) \\
\hline StopA & 5'-TYAAASTAATCTGASASTTCCRT-3' & $3032-3054$ & neoverrucotoxin_ $\alpha(\mathrm{AB} 262392)$ & Ueda et al. (2006) \\
\hline StopB & 5'-TTACAATAKTTTAATYYGACCATT-3' & $2158-2181$ & neoverrucotoxin_ $\beta$ (AB262393) & \\
\hline Stop_marA & 5'-TCAAAGTAAATTGGCCTTTCCG-3' & $2181-2202$ & cDNA of SmTx_A(KJ689807) & This study \\
\hline Stop_marB & 5'-TTAAAGTAATTTAATCTGGCCCTTGC-3' & $2173-2198$ & cDNA of SmTx_B (KJ689808) & \\
\hline \multicolumn{5}{|c|}{ Gene specific primers for $S$. strongia } \\
\hline str3A1 & 5'-CGACCTACAAGACACTTCC-3' & $771-789$ & cDNA of SsTx_A (KJ689803) & This study \\
\hline str3A2 & 5'-CATGGCTCCTGCGAAGACTATC-3' & $1615-1636$ & & \\
\hline str3B1 & 5'-CCТАССАТСААСТТССАСАA-3' & 774-793 & cDNA of SsTx_B (KJ689804) & \\
\hline str3B2 & 5'-GATCATCAATGACTTTAGCAAG-3' & $1582-1603$ & & \\
\hline str5_RACE & 5'-TTGTCACTGTCAAAGAC-3' & $557-573$ & cDNA of SsTx_A (KJ689803) & \\
\hline str5A1 & 5'-GTTGCCACGTTCTTGTCAGA-3' & $513-494$ & & \\
\hline str5A2 & 5'-GGAGGAGCTTTGAATTGTTGAT-3' & $462-441$ & & \\
\hline str5B1 & 5'-GTTGCCTCAATGTTCTGAAA-3' & $513-494$ & cDNA of SsTx_B (KJ689804) & \\
\hline str5B2 & 5'-AGATTAGTCATCAGCTGTTTGA-3' & $462-441$ & & \\
\hline \multicolumn{5}{|c|}{ Gene specific primers for S. oxycephala } \\
\hline oxy3A1 & 5'-GATTCCTACTGTTAGCATTGAG-3' & $626-647$ & cDNA of SoTx_A (KJ689805) & This study \\
\hline oxy3A2 & 5'-GAGAGGTTTGACAACTACCG-3' & $1767-1786$ & & \\
\hline oxy3B1 & 5'-GATAGCAGCACTCCAATACT-3' & $877-896$ & cDNA of SoTx_B (KJ689806) & \\
\hline оху3В2 & 5'-AACAAGAAGGCAATGTCTGG-3' & $1714-1733$ & & \\
\hline oxy5_RACE & 5'-CTTTATCACAGCTTCC-3' & $623-608$ & cDNA of SoTx_A (KJ689805) & \\
\hline oxy5A1 & 5'-TGTCCTGAAGGTTGCTGTCC-3' & $594-575$ & & \\
\hline oxy5A2 & 5'-CCAGGAGGAGCTTTGAAT-3' & $460-443$ & & \\
\hline oxy5B1 & 5'-CACTACATGAGTTGCCTCAATG-3' & $519-498$ & cDNA of SoTx_B (KJ689806) & \\
\hline oxy5B2 & 5'-GGTTTCAAGATTAGTCATCAGC-3' & $465-444$ & & \\
\hline \multicolumn{5}{|c|}{ Gene specific primers for $S$. marmoratus } \\
\hline mar3A1 & 5'-CCAAGTCACCATTCAGCAAT-3' & $1139-1158$ & cDNA of SmTx_A (KJ689807) & This study \\
\hline $\operatorname{mar} 3 \mathrm{~A} 2$ & 5'-GACCCAAACACAGTACACAA-3' & $1690-1709$ & & \\
\hline mar3B1 & 5'-TGTGGATGGAATGTGAAGAA-3' & $1168-1187$ & cDNA of SmTx_B(KJ689808) & \\
\hline mar3B2 & 5'-GCCCTGACTCTGTCTGA-3' & $1701-1717$ & & \\
\hline mar5_RACE_A & 5'-AGCCACACCTTCATT-3' & $836-822$ & cDNA of SmTx_A(KJ689807) & \\
\hline mar5A1 & 5'-AGTCCTGGAAGATTCTGGTATG-3' & $791-770$ & & \\
\hline $\operatorname{mar} 5 \mathrm{~A} 2$ & 5'-GTTGCTATCCTCTAACTTGTC-3' & $585-565$ & & \\
\hline mar5_RACE_B & 5'-AGGTGCTTCAGAGTAA-3' & $866-851$ & cDNA of SmTx_B (KJ689808) & \\
\hline mar5B1 & 5'-GTGGAAGTTGCTGGTAGG-3' & $789-772$ & & \\
\hline mar5B2 & 5'-AAGAAGTCGCCGTGGAA-3' & $730-714$ & & \\
\hline \multicolumn{5}{|c|}{ Gene specific primers for $D$. zebra } \\
\hline zebA_F & 5'-TCCAACTGACTGATGAAGAA-3' & $814-833$ & gDNA of $D z T x \_A(\mathrm{KJ} 689800)$ & This study \\
\hline zebB_F & 5'-CTCTGGAAGACAACATAGTC-3' & $2347-2366$ & gDNA of $D z T x \_B(\mathrm{KJ} 689801)$ & \\
\hline zebC_F & 5'-CTCTGGAAGACAACACAGTG-3' & $1339-1358$ & gDNA of DzTx_C (KJ689802) & \\
\hline zeb3A1 & 5'-TCAAGGAGCAAGCATCTAC-3' & $1709-1727$ & gDNA of $D z T x \_A(\mathrm{KJ} 689800)$ & \\
\hline zeb3A2 & 5'-TCTTTAGCACTTCССТCСТ-3' & $1866-1884$ & & \\
\hline zeb3B1 & 5'-ACCTCTGTGGAAGACTACG-3' & $2709-2727$ & gDNA of $D z T x \_B(\mathrm{KJ} 689801)$ & \\
\hline zeb3B2 & 5'-ААСТССААССАССАССАA-3' & $2791-2808$ & & \\
\hline zeb3C1 & 5'-TGCTATGTCTTCACCTATGT-3' & $1689-1708$ & gDNA of DzTx_C (KJ689802) & This study \\
\hline zeb3C2 & 5'-ACTTCTTGGATTCACCTACA-3' & $1744-1763$ & & \\
\hline zeb5A1 & 5'-CGGACATATCTTCTGTTCTTC-3' & $1675-1655$ & gDNA of $D z T x \_A(\mathrm{KJ} 689800)$ & \\
\hline zeb5B1 & 5'-TTCAGCACCTTTCTAATTTGA-3' & $2398-2378$ & gDNA of $D z T x \_B(\mathrm{KJ} 689801)$ & \\
\hline zeb5C1 & 5'-TGTAGGTGAATCCAAGAAGT-3' & $1763-1744$ & gDNA of DzTx_C (KJ689802) & \\
\hline
\end{tabular}

regions. The determined lengths of the three partial genes in $D$. zebra are 2220 bp $\left(D z T x \_A\right), 3704$ bp $\left(D z T x \_B\right)$, and 3091 bp $\left(D z T x_{-} C\right)$. The accession numbers of all the determined genomic DNA sequences and the lengths of introns and exons are listed in Table 3.
3.4. Intron-exon location in S. strongia, S. oxycephala, and S. marmoratus

Alignment of the toxin genes' cDNA with sequences determined from genomic DNA shows that both toxin 
Table 3

Accession numbers and lengths of the toxin genes determined from cDNA and genomic DNA templates.

\begin{tabular}{|c|c|c|c|c|c|c|c|}
\hline & Accession number & Total length & & $5^{\prime}$ UTR & CDR (DNA/amino acid) & & $3^{\prime}$ UTR \\
\hline \multicolumn{8}{|l|}{ cDNA } \\
\hline SsTX_A & KJ689803 & $>2209 \mathrm{bp}^{\mathrm{a}}$ & & $97 \mathrm{bp}$ & 2112 bp/703 a.a. & & Undetermined $^{\mathrm{a}}$ \\
\hline SsTX_B & KJ689804 & $>2194 \mathrm{bp}^{\mathrm{a}}$ & & $97 \mathrm{bp}$ & 2097 bp/698 a.a. & & Undetermined $^{\mathrm{a}}$ \\
\hline SoTx_A & KJ689805 & $2410 \mathrm{bp}$ & & $92 \mathrm{bp}$ & 2112 bp/703 a.a. & & 206 bp \\
\hline SoTx_B & KJ689806 & $2428 \mathrm{bp}$ & & $93 \mathrm{bp}$ & 2097 bp/698 a.a. & & 238 bp \\
\hline$S m T x \_A$ & KJ689807 & 2437 bp & & 93 bp & 2109 bp/702 a.a. & & 235 bp \\
\hline \multirow[t]{2}{*}{ SmTx_B } & KJ689808 & $2519 \mathrm{bp}$ & & $95 \mathrm{bp}$ & 2103 bp/700 a.a. & & $321 \mathrm{bp}$ \\
\hline & Accession number & Total length & Exon_1 & Intron_1 & Exon_2 & Intron_2 & Exon_3 \\
\hline \multicolumn{8}{|c|}{ Genomic DNA } \\
\hline SsTx_A & KJ689794 & 5011 bp & $91 \mathrm{bp}$ & 2273 bp & 1473 bp & 626 bp & 548 bp \\
\hline$S s T x \_B$ & KJ689795 & 3988 bp & $91 \mathrm{bp}$ & 542 bp & 1467 bp & 1349 bp & 539 bp \\
\hline SoTx_A & KJ689796 & 4838 bp & $91 \mathrm{bp}$ & 2114 bp & $1473 \mathrm{bp}$ & 612 bp & 548 bp \\
\hline SoTx_B & KJ689797 & 3488 bp & $91 \mathrm{bp}$ & 542 bp & 1467 bp & 849 bp & 539 bp \\
\hline$S m T x \_A$ & KJ689798 & 3158 bp & $91 \mathrm{bp}$ & 243 bp & $1485 \mathrm{bp}$ & 806 bp & $533 \mathrm{bp}$ \\
\hline$S m T x \_B$ & KJ689799 & $3821 b p$ & $91 \mathrm{bp}$ & 542 bp & 1473 bp & 1176 bp & 539 bp \\
\hline$D z T x \_A$ & KJ689800 & $>2220 \mathrm{bp}$ & 88 bp & 248 bp & 1485 bp & 214 bp & $>185 \mathrm{bp}^{\mathrm{a}}$ \\
\hline$D z T x \_B$ & KJ689801 & $>3704$ bp & $91 \mathrm{bp}$ & 1484 bp & 1479 bp & 465 bp & $>185 b^{a}$ \\
\hline$D z T x \_C$ & KJ689802 & >3091 bp & $91 \mathrm{bp}$ & 476 bp & 1473 bp & 866 bp & $>185 \mathrm{bp}^{\mathrm{a}}$ \\
\hline
\end{tabular}

a The lengths of the $3^{\prime}$ UTRs of SsTx_A and $S s T x \_B$, and exon_3 in DzTx_A,DzTx_B, and DzTx_C are undetermined since no PCR products were obtained.

subunits in all three species are constructed by 3 exons and 2 introns. The positions of intron_1 in both two toxin subunits of all three species are at the first base of Gly 31 (intron phase 1 ). For the $\alpha$ subunit genes of $S$. strongia (SsTx_A) and $S$. oxycephala (SoTx_A), the positions of intron_2 are at the first base of Tyr 522 (phase I), while for the $\alpha$ subunit gene of $S$. marmoratus (SmTx_A), intron_2 is located at the first base of Tyr 526 (phase I). For the $\beta$ subunit genes of $S$. strongia $\left(S s T x_{-} B\right)$ and $S$. oxycephala (SoTx_B), the positions of intron_2 are at the first base of Tyr 520 (phase I) and for S. marmoratus (SmTX_B), the intron_2 is positioned at the first base of Tyr 522 (phase I). The distribution patterns of exons and introns in the two subunit genes of $S$. strongia, $S$. oxycephala, and $S$. marmoratus are depicted in Fig. 2.

\subsection{Intron-exon prediction in D. zebra}

Since the stonustoxin gene determined by Ghadessy et al. (1996) and the toxin genes of S. strongia, S. oxycephala, and $S$. marmoratus examined in this study are conserved in intron positions, we predicted that the ORFs of the three toxin genes in D. zebra are interrupted by introns in similar positions (intron_1: Gly 30 in $D z T x \_A$, Gly 31 in DzTx_B and DzTx_C, intron_2: Tyr 522 in DzTx_A, Tyr 525 in $D z T x \_B$, and Tyr 524 in $D z T z_{-} C$ ). The partial ORFs of the three subunits in $D$. zebra were predicted to be 1758 bp $\left(D z T x \_A\right), 1755$ bp $\left(D z T x \_B\right)$ and 1749 bp $\left(D z T x \_C\right)$. The GenBank accession numbers and the predicted lengths of the introns and exons of these three toxin genes in D. zebra are listed in Table 3 and the predicted exon-intron distributions are shown in Fig. 3.

\subsection{Coding region and deduced amino acid sequences analysis}

For the whole available scorpaenoid toxin sequences, the averaged $d_{\mathrm{N}} / d_{\mathrm{S}}$ value is 0.719 . The similarity test of the deduced amino acid sequences is shown in Table 4. The similarity of the $\alpha$ subunits of $S$. strongia, $S$. oxycephala, and S. marmoratus (SsTx_A, SoTx_A and SmTx_A) to the $\alpha$ subunits of stonustoxin and neoverrucotoxin are about $73 \%$ (69-77\%), while similarity of the $\beta$ subunits (SsTx_B, SoTx_B and SmTx_B) to the $\beta$ subunits of stonustoxin and neoverrucotoxin are about $78 \%(76-80 \%)$. The two subunits in each species are about 55\% similar. Alignment of the deduced amino acid sequences shows that 208 out of the 710 amino acid residues (including gaps) are conserved in all the sequences. Among them, 5 Cys (205, 375, 407, 528 and 575) and $6 \operatorname{Trp}(247,361,525,585,589$ and 620) are conserved in all sequences. For positively charged residues (Lys and Arg), 23 sites (13, 24, 65, 91, 97, 98, 104, 110, 159, $177,178,271,272,286,305,327,332,373,385,395,474$, 497, and 520) are charge-conserved among all sequences (Supplementary Table 1).

\subsection{Phylogenetic analysis}

When using JTT $+\mathrm{G}$ as the substitution model, both tree-constructing methods (ML and MP) depict similar topologies (Fig. 4). The two subunit genes from all species form distinct groups (named clade A and clade B) except for the two subunits of Pterois, which are grouped together and are branched from clade B (named subclade P). In both clade A and B, the sequences of Synanceiidae (S. horrida, Synanceia verrucosa, and I. japonicus) and Tetrarogidae (H. rubripinnis) are grouped together and form the basic branches. Within these two clades, $S$. strongia and $S$. oxycephala are grouped together and $S$. marmoratus forms a sister group. If we disregard the toxin genes of Pterois (subclade P), the sequences in both clades almost form a mirror image. For the three species of genus Pterois, these two subunit genes form distinct groups but the intra-group relationships are not perfectly mirrored. The main branches are all strongly supported by the ML and MP methods with bootstrap values higher than $90 \%$. 

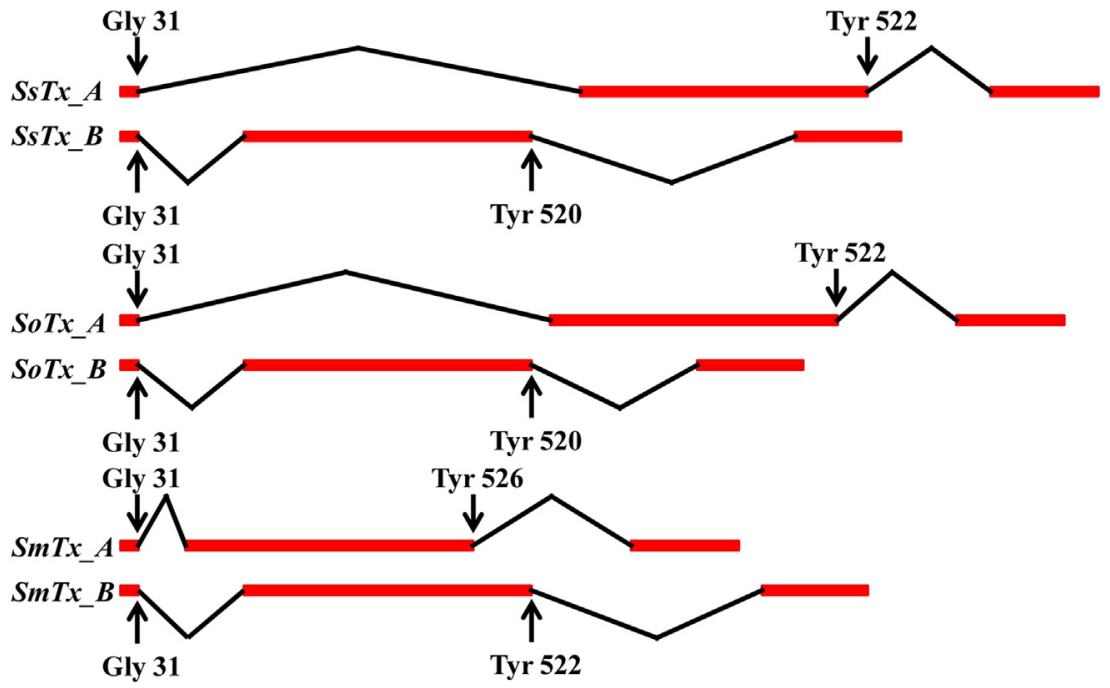

Fig. 2. The distribution of introns and exons of the two toxin subunit genes in S. strongia, S. oxycephala, and S. marmoratus. The exons are represented as red bars and introns as black lines connecting the exons. (For interpretation of the references to color in this figure legend, the reader is referred to the web version of this article.)

Combining the predicted ORFs of the three toxin genes of $D$. zebra into the phylogenetic analysis shows similar topologies as illustrated in Fig. 4. In both phylogenetic trees, $D z T x \_A$ is posited at clade $A$, while $D z T x \_B$ and $D z T x \_C$ are grouped with the sequences of Pterois in the subclade $P$ (Fig. 5). For the main branches in these trees, bootstrap values are all higher than $90 \%$, suggesting the robustness of the grouping results. However, the finer branches within subclade P are not strongly supported by the trees, with bootstrap values lower than $70 \%$ and the intra-group relationships of the toxin genes of the four species are not consistent in the trees.

\section{Discussion}

4.1. High similarity and evolutionally negative selection of the toxins

The toxin cDNA sequences obtained in this study are 2209 bp and 2194 bp for the $\alpha$ and $\beta$ subunits in S. strongia, 2410 bp and 2428 bp in S. oxycephala, and 2437 bp and
2519 bp in S. marmoratus. Although we were not able to get the 3' UTR sequences in S. strongia, the degenerate primers stopA and stopB succeeded in amplifying the toxin genes from the cDNA templates and thus have completed the coding region sequences. For the lengths of all these toxin genes obtained in this study, the coding regions (2094-2109 bp) are about the same size as in stonustoxin (U32516, U36237), neoverrucotoxin (AB262392, AB262393), and in lionfish and waspfish (Ghadessy et al., 1996; Ueda et al., 2006; Kiriake and Shiomi, 2011; Kiriake et al., 2013). The value of $d_{N} / d_{S}(0.719)$, together with the high similarities between the toxin genes, suggests that these genes are under negative selection, which prevents deleterious mutations from accumulating (Fay et al., 2001). Since the venoms of these fish are mainly used as defensive weapons (Khoo, 2002; Lee et al., 2004; Gomes et al., 2011), the conservation (or convergence) of the toxin structures can enhance the memorization of predators. When being hurt by these toxins, it might keep the predator them from hunting morphologically similar fishes in the future.

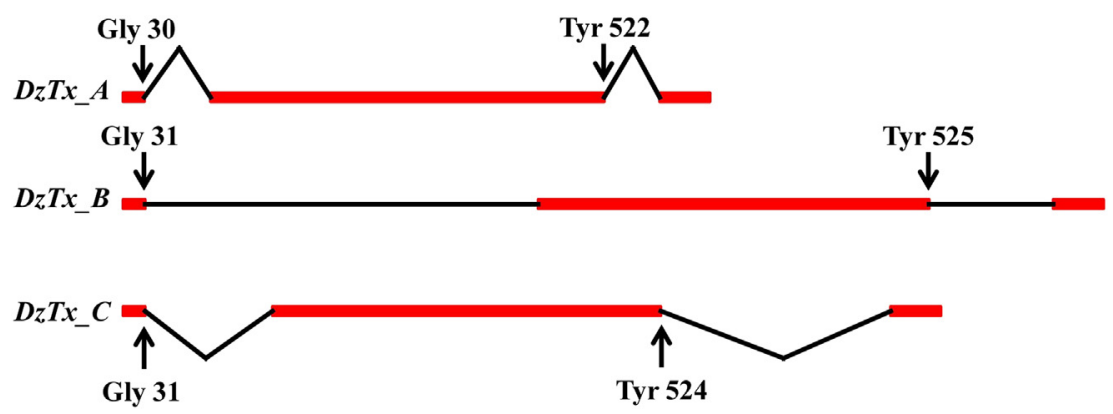

Fig. 3. The distribution of introns and exons of the three toxin genes in D. zebra. The exons are represented as red bars and introns as black lines connecting the exons. (For interpretation of the references to color in this figure legend, the reader is referred to the web version of this article.) 
Table 4

Global similarity of the deduced amino acid sequences of the toxin genes obtained in this study and those from the database.

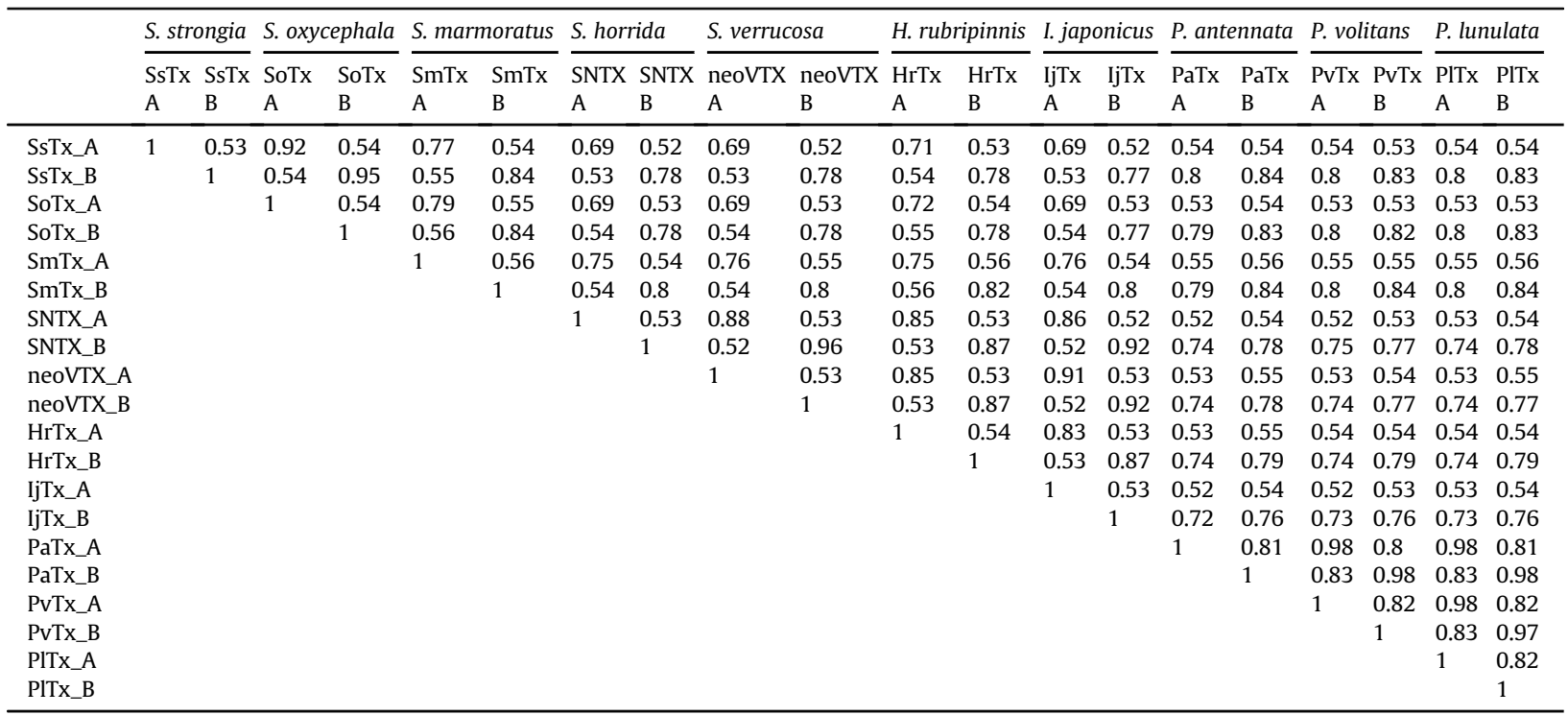

\subsection{Conservation of amino acid residues with important} functions

The conserved regions seen in the deduced amino acid sequences provide useful information for inferring possible reaction sites or sites significant in structuring the venom proteins. By forming inter- or intrachain disulfide bonds, cysteine is considered as a critical amino acid in shaping and stabilizing the conformation of proteins (Bardwell et al., 1991; Doig and Williams, 1991; Sevier and Kaiser, 2002). Since the 5 Cys conserved in all the venom peptides are the same as published by Kiriake and Shiomi (2011) and these cysteine residues were inferred to be involved in intrachain S-S linkages (Ghadessy et al., 1996), it is plausible that the two subunits possess similar structures and functions.

In contrast to the conformational role of cysteines, tryptophan and cationic residues such as lysine and arginine have been shown to be essential in the cytolytic activities of various pore-forming toxins by constituting the hydrophobic surfaces of the proteins (Kini and Evans, 1989b; Yew and Khoo, 2000). In the stonefish toxin SNTX, oxidation of tryptophan residues by NBS (N-bromosuccinimide) can modify about 10 of the 20 total tryptophan residues in the toxin and cause the loss of the hemolytic activity (Yew and Khoo, 2000). Our study shows that 6 tryptophan residues are conserved among all the venom peptides (12 tryptophan residues per venom protein). It is possible that these tryptophan residues are the corresponding amino acid sites being oxidized as reported by Yew and Khoo (2000). As for the cationic residues, a previous study showed that modifying the positively charged side chains of lysine or arginine reduces the hemolytic activity of SNTX, but does not significantly change its secondary structure (Chen et al., 1997). Our result shows that 23 amino acid sites are positively charge-conserved in all the scorpaenoid toxin sequences. These residues are therefore assumed to play essential roles in the hemolytic and lethal activities of these toxins. Systematic comparative studies of the hemolytic activities of all these toxins and site-directed mutagenesis studies should provide further information about the roles of these residues.

\subsection{Functional unit of the toxins}

The venom proteins have long been acknowledged as heterodimers due to the observation of about $150-160 \mathrm{kDa}$ products in the native condition and two different subunits in SDS-PAGE (Poh et al., 1991; Ueda et al., 2006). However, the study on $S$. verrucosa showed another venom protein (named VTX) that possesses two subunits but has a tetrameric structure (Garnier et al., 1995). The venom protein of Scorpaena plumieri was also reported to be capable of aggregating into even larger complexes (Gomes et al., 2013). By uniting into functional complexes, the toxins form transmembrane pores that lead to the lysis of the cells (Chen et al., 1997; Ueda et al., 2006; Gomes et al., 2013). The released cellular components may bind to the SP receptors on the endothelium and trigger the synthesis of nitric oxide (NO), which then causes the subsequent vasorelaxation and hypotension (Ghadessy et al., 1996; Sung et al., 2002; Liew et al., 2007). Although there is still some controversy about the actual mechanism of hemolysis, the functional diameters of the transmembrane pores have been determined by studies using osmotic protectants (polyethylene glycol polymers) in S. horrida and S. plumieri (Chen et al., 1997; Gomes et al., 2013). However, the impedance results shown in these studies occur in a gradual way rather than showing a threshold of osmotic protectant size (Fig. 1 in Chen et al., 1997 and Fig. 3 in Gomes et al., 2013). It is likely that the sizes of the pores formed by the toxins are not constants but are associated with the number of toxin molecules involved. 
a

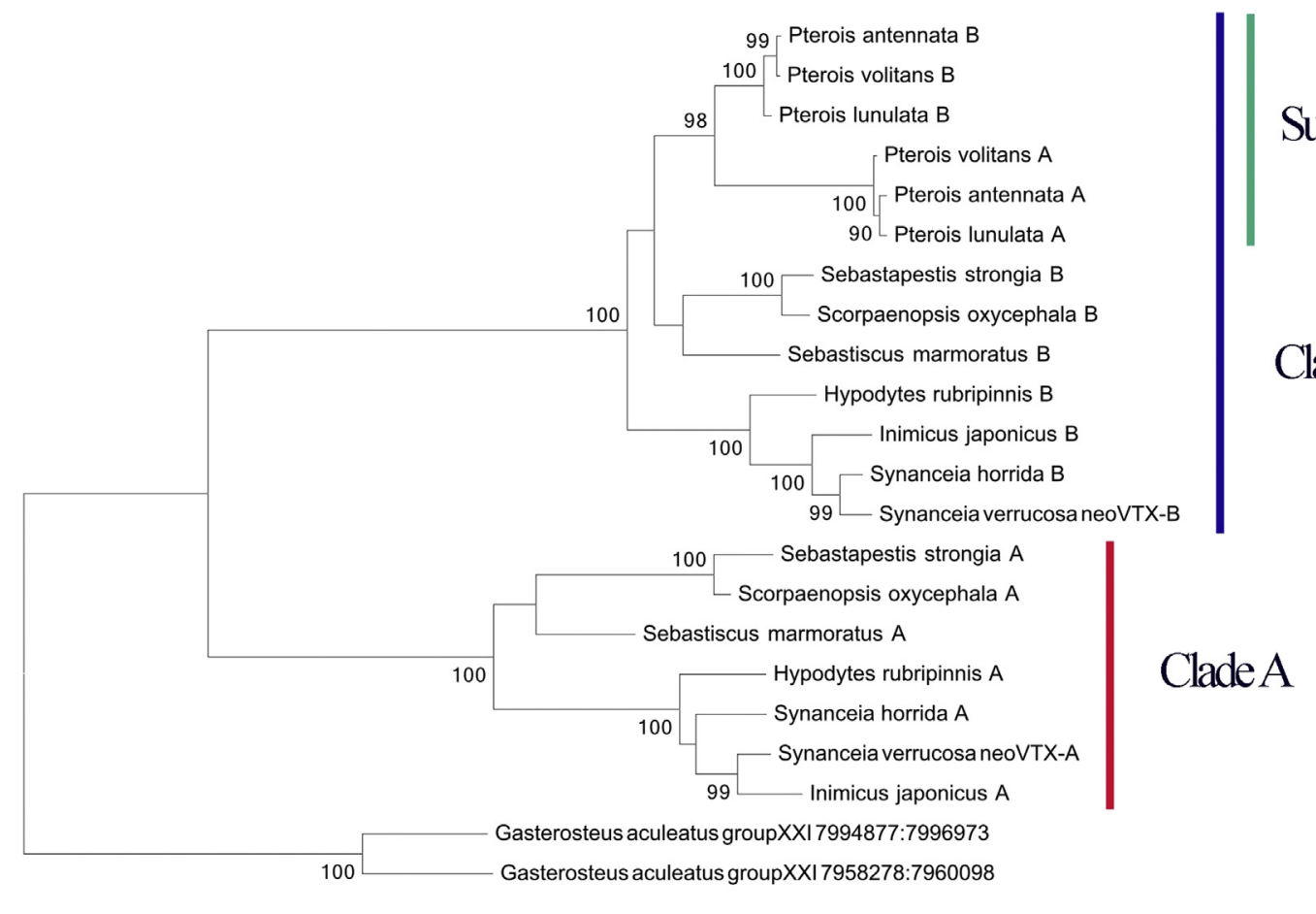

0.1

$\mathrm{b}$

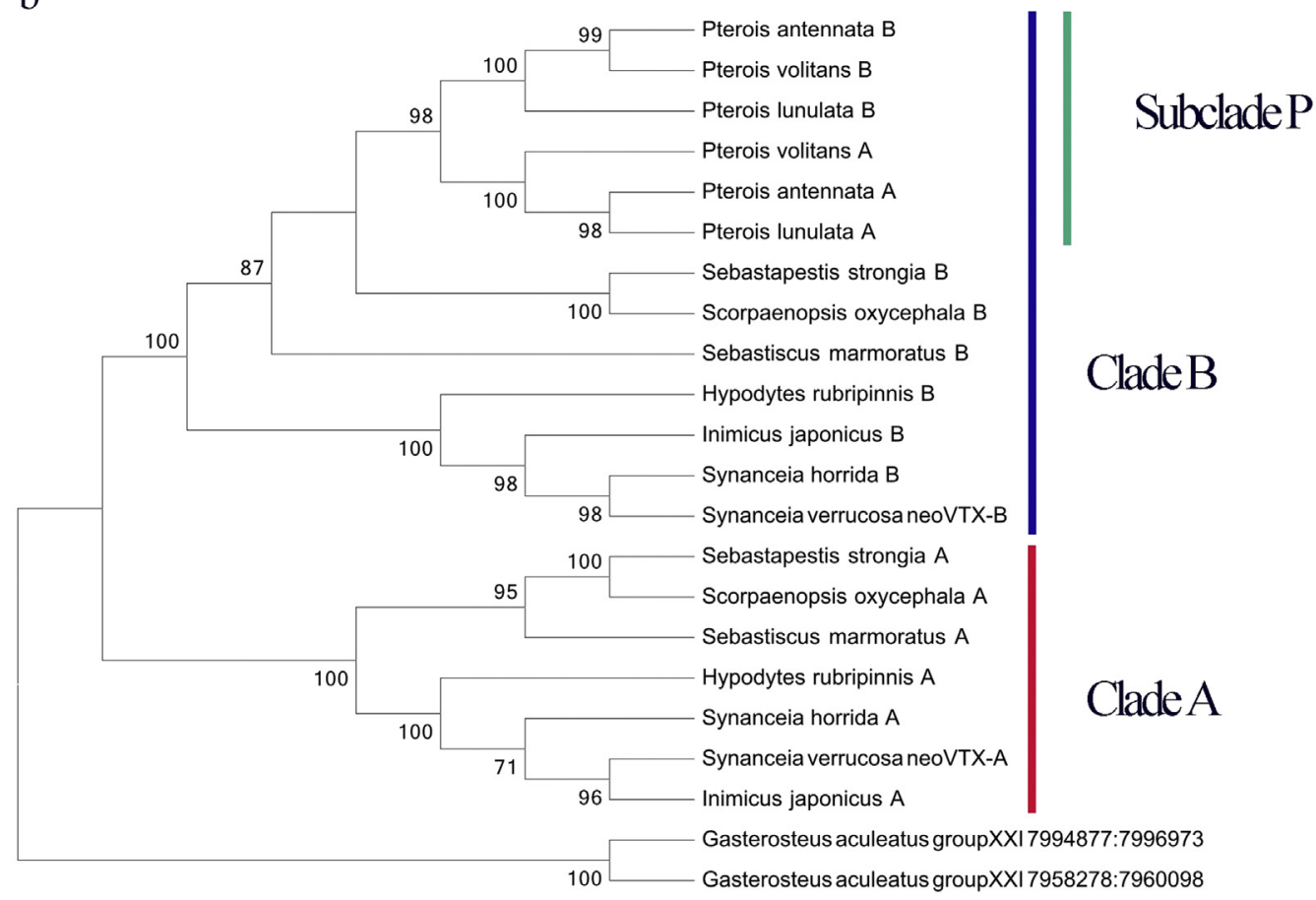

Fig. 4. Phylogenetic analyses of the toxin genes from S. strongia, S. oxycephala, and S. marmoratus using the maximum likelihood (panel a) and maximum parsimony (b) methods. Only bootstrap values $>70 \%$ are shown in the figure. 


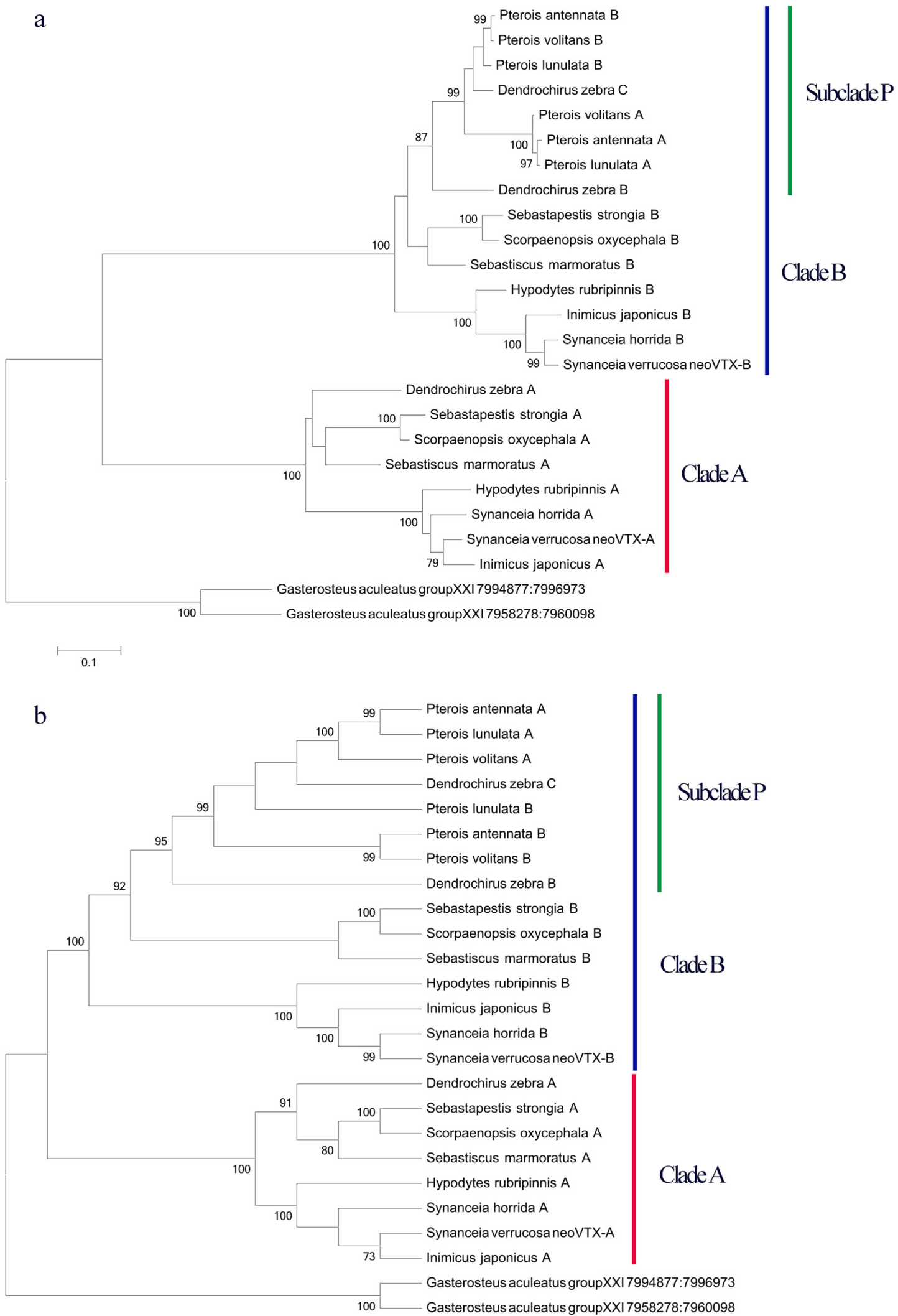

Fig. 5. Phylogenetic analyses of the toxin genes from S. strongia, S. oxycephala, S. marmoratus, and D. zebra using the maximum likelihood (panel a) and maximum parsimony (b) methods. Only bootstrap values $>70 \%$ are shown in the figure. 
Our study shows that these two toxin subunits are highly similar in primary (sequences similarity) and secondary structures (cysteine positions) and therefore may have redundant functions. In considering this redundancy and the gradualness of the impedance described above, the functional unit of the toxins may not be obligatorily heterodimeric as previously acknowledged. In our conjecture, the toxins are protein complexes that are formed by the two subunits with no fixed number or ratio. Since no studies have been conducted on the properties of the two subunits independently, the actual functional unit and the roles of the two individual subunits deserve further investigation.

\subsection{Conservative nature of intron positions}

Alignment of the CDRs (predicted CDRs in D. zebra) of the cDNA with the determined genomic toxin genes shows similar intron-exon distribution patterns, with 3 exons separated by 2 introns. The introns are all categorized as phase I and are flanked by GT and AG at the $5^{\prime}$ and $3^{\prime}$ ends, the most common consensus splicing sites discovered (Mount, 1982). For all the toxin sequences determined in this study, the positions of the two introns are largely conserved. Though there are some inconsistencies between the positions of introns_2 in the toxin genes, it can be attributed to the independent insertions/deletions in the two subunits. Disregarding the minor difference in intron_2 positions, the whole distribution of exons and introns are highly conserved among all sequences obtained in this study. The conservative nature of the positions and sequences on splicing sites indicates that the occurrences of the introns in these toxin genes are earlier than the duplication of the two subunits and the differentiation of these species. In addition, the conservative nature also implies that the open reading frames of the toxin genes in other scorpaenoid species can be predicted from their genomic DNA without obtaining the cDNA sequences.

\subsection{Toxin gene duplication before scorpaenoid speciation}

The deduced amino acid sequences of the toxin genes obtained in this study are highly similar to the toxin genes of stonefish and lionfish. The similarities from both toxin structures and amino acid sequences suggest the existence of a common ancestor for these genes in the Scorpaenoidei, or even at the higher level of Scorpaeniformes. Although this idea has been proposed in many studies (Ghadessy et al., 1996; Ueda et al., 2006; Kiriake and Shiomi, 2011), no one ever analyzed the toxin genes with an evolutionary perspective. The phylogenic trees constructed in this study show a general topology that the two subunits genes form distinct groups (clade A vs. clade B) and the finer branches are largely mirrored (disregarding those genes from the subfamily, Pteroinae). The clear separation of $\alpha$ and $\beta$ subunits indicates that the duplication and differentiation of these two genes occurred prior to the speciation of the Scorpaenoid fish. Unfortunately, the lack of fossil evidence and reliable evolutionary data precludes the estimation of the timings for the speciation and the toxin gene duplication event.

\subsection{Gene gain and loss in subfamily Pteroinae}

Regarding the toxin genes in lionfish, the two subunits of genus Pterois as well as DzTx_B and DzTx_C (from D. zebra) are grouped together and form a distinct group branching from clade $\mathrm{B}$. The position of this branch (subclade $\mathrm{P}$ ) indicates that the toxin genes of Pterois (and DzTx_B and $D z T x \_C$ ) originated from the $\beta$ subunit genes of Scorpaenoidei and an additional duplication event occurred prior to the speciation of subfamily Pteroinae. However, the precise timings of this duplication and speciation are speculative due to the insufficiency of evidence.

Another point of interest is that the toxin genes obtained from the cDNA libraries of three Pterois species showed no homology to $D z T x \_A$ in these lionfish (Kiriake and Shiomi, 2011; Kiriake et al., 2013). Since $D z T x \_A$ was found more homologous to the $\alpha$ subunit genes of Scorpaenoidei (clade $\mathrm{A}$ ), one possible explanation for the presence of this clade's A-homology was that the $D z T x \_A$ was a pseudogene and its function was replaced by the two genes duplicated from clade B $\left(D z T x \_B\right.$ and $\left.D z T x \_C\right)$. However, we cannot exclude the possibility that the existence of $D z T x \_A$ is a species-specific case and all these three toxin genes in D. zebra are functional, while the clade A gene in genus Pterois is completely lost. The genomic DNA sequencing of the toxin genes in Pterois species can provide useful evidence as to which hypothesis is correct.

Since the purified toxins from both lionfish (PvTx and PaTx) and stonefish (SNTX and neoVTX) show no significant difference in their properties, the duplication and pseudogenization seem to have occurred as random events, However, the possibility that this replacement processes confers some advantages for lionfish cannot be excluded.

\subsection{Possible evolutionary pathway of the toxin genes in the Scorpaenoidei}

From the perspective of gene duplication, a possible evolutionary pathway for the whole gene family is summarized and depicted in Fig. 6. Since the two outgroup sequences searched from GenBank are stonustoxin_ $\alpha$-homology and no homology of the $\beta$ subunit of stonustoxin was found in the genome of the three-spined stickleback (G. aculeatus), the first origin of the toxin genes may be traced back to the lineage leading to the Gsterosteiformes and Scorpaeniformes. However, the phylogenetic position of Gasterosteidae is controversial (Cuvier and Latreille, 1829; Cushing, 1984, Chen et al., 2003; Miya et al., 2003; Smith and Wheeler, 2004) and some studies suggested that Gasterosteidae should be a member of the Socrpaeniformes (Cuvier and Latreille, 1829; Regan, 1913; Miya et al., 2003). It is therefore possible that the toxin genes originated in the lineage leading to Scorpaeniformes and evolved into the toxin function specifically in Scorpaenoidei. In the lineage of the Scorpaeniformes, the ancestor toxin gene was duplicated in the ancestral species of the Scorpaenoidei (or in the mother species of the Scorpaeniformes) and persisted through the speciation of the Scorpaenoidei, where it evolved to $\alpha$ and $\beta$ subunit genes in the scorpaenoid analyzed in this study. Before the speciation of Pteroinae, the original $\beta$ subunit gene duplicated once again and became two subunit genes in Pterois (DzTx_B and DzTx_C 


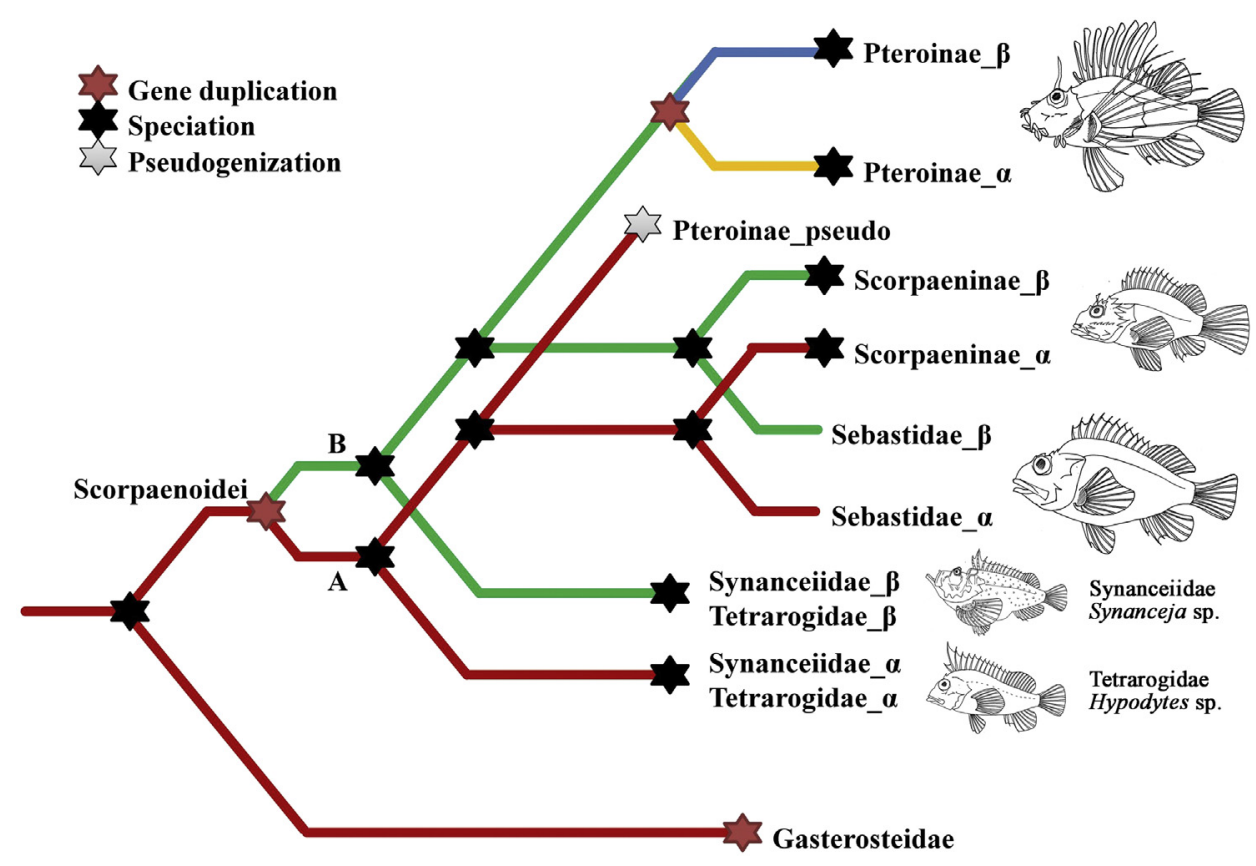

Fig. 6. Demonstration of the evolutionary history of the toxin genes in the Scorpaenoidei. Gray star indicates the pseudogenization of the toxin gene, brown stars indicate the duplication events of the toxin genes and black stars indicate the timing of speciation. (For interpretation of the references to color in this figure legend, the reader is referred to the web version of this article.)

in D. zebra). The speciation of the subfamily Pteroinae is likely an adaptive radiation and thus the intra-subfamily relationships could not be clearly resolved. In Pteroinae, the newly derived toxin subunit might have replaced the role of the original $\alpha$ subunit as a component of the toxin, while the original $\alpha$ subunit gene became a pseudogene. Since our evolutionary analysis is based on a relatively small number of species in the Scorpaenoidei, further study with more samples in the Scorpaeniformes should be conducted to test the origin of these toxin genes.

\section{Conclusion}

In this study we determined the toxin genes from four scorpaenoid species and reconstructed the possible evolutionary history of these genes. The results show that these toxins are under negative selection and suggest that they are commonly present in the whole Scorpaenoidei. Sequence alignment and phylogenetic results indicate that gene duplication explains the origin of all of these genes. Although we cannot determine the actual timing of toxin gene origination, we believe it to be prior to the speciation of the Scorpaeniformes. We did not test the bioactivity of the toxins of $S$. strongia, S. oxycephala, and S. marmoratus. However, it is likely they all share similar bioactivities and hemolytic activities as the toxins in stonefish and lionfish. The actual mechanism of the cytolytic activity of these toxins deserves further investigation.

\section{Acknowledgment}

We are grateful to Pung-Pung Hwang for the kind help in RT-PCR and RACEs experiments and to Brian Jessop for useful comments. This study was financially supported by the Ministry of Science and Technology of Taiwan (NSC 102-2611-M-002-009).

\section{Conflicts of interests}

The authors declare that there are no conflicts of interest.

\section{Transparency document}

Transparency document related to this article can be found online at http://dx.doi.org/10.1016/j.toxicon.2014.06. 013.

\section{Appendix A. Supplementary data}

Supplementary data related to this article can be found at http://dx.doi.org/10.1016/j.toxicon.2014.06.013.

\section{References}

Andrich, F., Carnielli, J.B., Cassoli, J.S., Lautner, R.Q., Santos, R.A. Pimenta, A.M., De Lima, M.E., Figueiredo, S.G., 2010. A potent vasoactive cytolysin isolated from Scorpaena plumieri scorpionfish venom. Toxicon 56, 487-496.

Bardwell, J.C., Mcgovern, K., Beckwith, J., 1991. Identification of a protein required for disulfide bond formation in vivo. Cell 67, 581-589.

Baron, A., Diochot, S., Salinas, M., Deval, E., No, L.J., Lingueglia, E., 2013. Venom toxins in the exploration of molecular, physiological and pathophysiological functions of acid-sensing ion channels. Toxicon 75, 187-204.

Carrijo, L.C., Andrich, F., De Lima, M.E., Cordeiro, M.N., Richardson, M., Figueiredo, S.G., 2005. Biological properties of the venom from the scorpionfish (Scorpaena plumieri) and purification of a gelatinolytic protease. Toxicon 45, 843-850. 
Chen, D.S., Kini, R.M., Yuen, R., Khoo, H.E., 1997. Haemolytic activity of stonustoxin from stonefish (Synanceia horrida) venom: pore formation and the role of cationic amino acid residues. Biochem. J. 325, 685-691.

Chen, W.J., Bonillo, C., Lecointre, G., 2003. Repeatability of clades as a criterion of reliability: a case study for molecular phylogeny of Acanthomorpha (Teleostei) with larger number of taxa. Mol. Phylogenetics Evol. 26, 262-288.

Chippaux, J.P., Goyffon, M., 1998. Venoms, antivenoms and immunotherapy. Toxicon 36, 823-846.

Church, J.E., Hodgson, W.C., 2002. The pharmacological activity of fish venoms. Toxicon 40, 1083-1093.

Cushing, D.H., 1984. Fishes of the World. In: Nature, second ed., vol. 312. Nelson, Js, p. 679.

Cuvier, G., Latreille, P.A., 1829. Le règne animal distribué d'après son organisation: Les crustacés, arachnides et partie des insectes, par M. Latreille, Deterville.

Doig, A.J., Williams, D.H., 1991. Is the hydrophobic effect stabilizing or destabilizing in proteins?: the contribution of disulphide bonds to protein stability. J. Mol. Biol. 217, 389-398.

Dutertre, S., Lewis, R.J., 2010. Use of venom peptides to probe ion channel structure and function. J. Biol. Chem. 285, 13315-13320.

Fay, J.C., Wyckoff, G.J., Wu, C.I., 2001. Positive and negative selection on the human genome. Genetics 158, 1227-1234.

Garnier, P., Ducancel, F., Ogawa, T., Boulain, J.C., Goudey-Perriere, F., Perriere, C., Menez, A., 1997a. Complete amino-acid sequence of the beta-subunit of VTX from venom of the stonefish (Synanceia verrucosa) as identified from cDNA cloning experiments. Biochim. Biophys. Acta $1337,1-5$

Garnier, P., Goudey-Perriere, F., Breton, P., Dewulf, C., Petek, F., Perriere, C., 1995. Enzymatic properties of the stonefish (Synanceia verrucosa Bloch and Schneider, 1801) venom and purification of a lethal, hypotensive and cytolytic factor. Toxicon 33, 143-155.

Garnier, P., Sauviat, M.P., Goudey-Perriere, F., Perriere, C., 1997b. Cardiotoxicity of verrucotoxin, a protein isolated from the venom of Synanceia verrucosa. Toxicon 35, 47-55.

Gazarian, K.G., Gazarian, T., Hernandez, R., Possani, L.D., 2005. Immunology of scorpion toxins and perspectives for generation of antivenom vaccines. Vaccine 23, 3357-3368.

Ghadessy, F.J., Chen, D.S., Kini, R.M., Chung, M.C.M., Jeyaseelan, K., Khoo, H.E., Yuen, R., 1996. Stonustoxin is a novel lethal factor from stonefish (Synanceia horrida) venom - cDNA cloning and characterization. J. Biol. Chem. 271, 25575-25581.

Gomes, H.L., Andrich, F., Fortes-Dias, C.L., Perales, J., Teixeira-Ferreira, A., Vassallo, D.V., Cruz, J.S., Figueiredo, S.G., 2013. Molecular and biochemical characterization of a cytolysin from the Scorpaena plumieri (scorpionfish) venom: evidence of pore formation on erythrocyte cell membrane. Toxicon 74, 92-100.

Gomes, H.L., Menezes, T.N., Carnielli, J.B.T., Andrich, F., Evangelista, K.S. Chavez-Olortegui, C., Vassallo, D.V., Figueiredo, S.G., 2011. Stonefish antivenom neutralises the inflammatory and cardiovascular effects induced by scorpionfish Scorpaena plumieri venom. Toxicon 57, 992-999.

Hahn, S.T., O'connor, J.M., 2000. An investigation of the biological activity of bullrout (Notesthes robusta) venom. Toxicon 38, 79-89.

Huston, J.S., George, A.J., 2001. Engineered antibodies take center stage. Hum. Antibodies 10, 127-142.

Jha, R., Zi-Rong, X., 2004. Biomedical compounds from marine organisms. Mar. Drugs 2, 123-146.

Khoo, H.E., 2002. Bioactive proteins from stonefish venom. Clin. Exp. Pharmacol. Physiol. 29, 802-806.

Khoo, H.E., Chen, D.S., Yuen, R., 1998. Role of free thiol groups in the biological activities of stonustoxin, a lethal factor from stonefish (Synanceia horrida) venom. Toxicon 36, 469-476.

Kini, R.M., Evans, H.J., 1989a. A common cytolytic region in myotoxins, hemolysins, cardiotoxins and antibacterial peptides. Int. J. Peptide Protein Res. 34, 277-286.

Kini, R.M., Evans, H.J., 1989b. Role of cationic residues in cytolytic activity: modification of lysine residues in the cardiotoxin from Naja nigricollis venom and correlation between cytolytic and antiplatelet activity. Biochemistry 28, 9209-9215.

Kiriake, A., Shiomi, K., 2011. Some properties and cDNA cloning of proteinaceous toxins from two species of lionfish (Pterois antennata and Pterois volitans). Toxicon 58, 494-501.

Kiriake, A., Suzuki, Y., Nagashima, Y., Shiomi, K., 2013. Proteinaceous toxins from three species of scorpaeniform fish (lionfish Pterois lunulata, devil stinger Inimicus japonicus and waspfish Hypodytes rubripinnis): close similarity in properties and primary structures to stonefish toxins. Toxicon 70, 184-193.

Kreger, A.S., 1991. Detection of a cytolytic toxin in the venom of the stonefish (Synanceia trachynis). Toxicon 29, 733-743.
Lee, J.Y.L., Teoh, L.C., Leo, S.P.M., 2004. Stonefish envenomations of the hand - a local marine hazard: a series of 8 cases and review of the literature. Ann. Acad. Med. Singap. 33, 515-520.

Liew, H.C., Khoo, H.E., Moore, P.K., Bhatia, M., Lu, J., Moochhala, S.M., 2007. Synergism between hydrogen sulfide (H2S) and nitric oxide (NO) in vasorelaxation induced by stonustoxin (SNTX), a lethal and hypotensive protein factor isolated from stonefish Synanceia horrida venom. Life Sci. 80, 1664-1668.

Lu, A., Yang, L., Xu, S., Wang, C., 2014. Various conotoxin diversifications revealed by a venomic study of Conus flavidus. Mol. Cell. Proteomics 13, 105-118.

Menez, A., 1998. Functional architectures of animal toxins: a clue to drug design? Toxicon 36, 1557-1572.

Miya, M., Takeshima, H., Endo, H., Ishiguro, N.B., Inoue, J.G., Mukai, T., Satoh, T.P., Yamaguchi, M., Kawaguchi, A., Mabuchi, K., Shirai, S.M., Nishida, M., 2003. Major patterns of higher teleostean phylogenies: a new perspective based on 100 complete mitochondrial DNA sequences. Mol. Phylogenetics Evol. 26, 121-138.

Mount, S.M., 1982. A catalogue of splice junction sequences. Nucleic Acids Res. 10, 459-472.

Muse, S.V., Gaut, B.S., 1994. A likelihood approach for comparing synonymous and nonsynonymous nucleotide substitution rates, with application to the chloroplast genome. Mol. Biol. Evol. 11, 715-724.

Nagasaka, K., Nakagawa, H., Satoh, F., Hosotani, T., Yokoigawa, K., Sakai, H., Sakuraba, H., Ohshima, T., Shinohara, M., Ohura, K., 2009. A novel cytotoxic protein, Karatoxin, from the dorsal spines of the redfin velvetfish, Hypodytes rubripinnis. Toxin Rev. 28, 260-265.

Newman, D.J., Cragg, G.M., 2012. Natural products as sources of new drugs over the 30 years from 1981 to 2010. J. Nat. Prod. 75, 311-335.

Poh, C.H. Yuen, R. Khoo, H.E., Chung, M., Gwee, M., Gopalakrishnakone, P., 1991. Purification and partial characterization of stonustoxin (lethal factor) from Synanceia horrida venom. Comp. Biochem. Physiol. B Biochem. Mol. Biol. 99, 793-798.

Regan, C.T., 1913. I.-The osteology and classification of the Teleostean fishes of the Order Scleroparei. Ann. Mag. Nat. Hist. 11, 169-184.

Schaeffer, R.C., Carlson, R.W., Russell, F.E., 1971. Some chemical properties of the venom of the scorpionfish Scorpaena guttata. Toxicon 9, 69-78.

Sevier, C.S., Kaiser, C.A., 2002. Formation and transfer of disulphide bonds in living cells. Nat. Rev. Mol. Cell Biol. 3, 836-847.

Shiomi, K., Hosaka, M., Fujita, S., Yamanaka, H., Kikuchi, T., 1989. Venoms from six species of marine fish: lethal and hemolytic activities and their neutralization by commercial stonefish antivenom. Mar. Biol. 103, 285-289.

Smith, W.L., Wheeler, W.C., 2004. Polyphyly of the mail-cheeked fishes (Teleostei : Scorpaeniformes): evidence from mitochondrial and nuclear sequence data. Mol. Phylogenetics Evol. 32, 627-646.

Smith, W.L., Wheeler, W.C., 2006. Venom evolution widespread in fishes: a phylogenetic road map for the bioprospecting of piscine venoms. J. Hered. 97, 206-217.

Sung, J.M.L., Low, K.S.Y., Khoo, H.E., 2002. Characterization of the mechanism underlying stonustoxin-mediated relaxant response in the rat aorta in vitro. Biochem. Pharmacol. 63, 1113-1118.

Tamura, K., Peterson, D., Peterson, N., Stecher, G., Nei, M., Kumar, S., 2011. MEGA5: molecular evolutionary genetics analysis using maximum likelihood, evolutionary distance, and maximum parsimony methods. Mol. Biol. Evol. 28, 2731-2739.

Tan, P.T., Khan, A.M., Brusic, V., 2003. Bioinformatics for venom and toxin sciences. Brief. Bioinform. 4, 53-62.

Terlau, H., Olivera, B.M., 2004. Conus venoms: a rich source of novel ion channel-targeted peptides. Physiol. Rev. 84, 41-68.

Theakston, R.D.G., 1983. The application of immunoassay techniques, including enzyme-linked immunosorbent assay (ELISA), to snake venom research. Toxicon 21, 341-352.

Ueda, A., Suzuki, M., Honma, T., Nagai, H., Nagashima, Y., Shiomi, K., 2006. Purification, properties and cDNA cloning of neoverrucotoxin (neoVTX), a hemolytic lethal factor from the stonefish Synanceia verrucosa venom. Biochim. Biophys. Acta 1760, 1713-1722.

Ward, R.D., Zemlak, T.S., Innes, B.H., Last, P.T., Hebert, P., 2005. DNA barcoding Australia's fish species. Philosophical Transactions of the Royal Society B: Biological Sciences 360, 1847-1857.

Wesolowski, J., Alzogaray, V., Reyelt, J., Unger, M., Juarez, K., Urrutia, M., Cauerhff, A., Danquah, W., Rissiek, B., Scheuplein, F., Schwarz, N., Adriouch, S., Boyer, O., Seman, M., Licea, A., Serreze, D.V., Goldbaum, F.A., Haag, F., Koch-Nolte, F., 2009. Single domain antibodies: promising experimental and therapeutic tools in infection and immunity. Med. Microbiol. Immunol. 198, 157-174.

Yew, W.S., Khoo, H.E., 2000. The role of tryptophan residues in the hemolytic activity of stonustoxin, a lethal factor from stonefish (Synanceia horrida) venom. Biochimie 82, 251-257. 